\title{
Oxygen Consumption in the American Oyster Crassostrea virginica
}

\author{
Sandra E. Shumway and Richard K. Koehn \\ Department of Ecology and Evolution, State University of New York, Stony Brook, New York 11794, USA
}

\begin{abstract}
Acclimated and acute rates of oxygen consumption of the American oyster Crassostrea virginica (Gmelin) were measured under 9 salinity-temperature combinations during declining oxygen tensions. In acclimated and non-acclimated individuals the basal rate of oxygen uptake increased significantly with each $10 \mathrm{C}^{\circ}$ rise in temperature. Multiple regression equations relating exposure and experimental temperatures and salinities to $\dot{\mathrm{V}} \mathrm{O}_{2}$ indicated: (1) as acclimation salinity decreased, the effect of exposure temperature became more pronounced; (2) as acclimation salinity decreased, the effect of exposure salinity decreased; (3) as acclimation temperature increased, the effect of exposure salinity decreased; (4) as acclimation temperature increased, the effect of exposure temperature increased. There is little or no evidence for temperature acclimation even after $3 \mathrm{wk}$. $\mathrm{Q}_{10}$ values for warm acclimated oysters were generally higher than those of cold adapted oysters with the exception of individuals acclimated at a salinity of $7 \% \mathrm{~S}$ and exposed to $28 \% \mathrm{~S}$. At any experimental salinity the highest $Q_{10}$ values were observed between 20 and $30^{\circ} \mathrm{C}$. C. virginica is well able to regulate $\dot{V} \mathrm{O}_{2}$ when exposed to declining oxygen tensions at all temperature-salinity combinations tested; this capacity decreased considerably at all test temperatures in oysters acclimated to $7 \%$ S. There is no clear pattern of response between exposure conditions and ability to regulate $\dot{\mathrm{V}} \mathrm{O}_{2}$; the degree of regulation decreases with increasing temperature and/or decreasing salinity. The results indicate that the respiratory physiology of $C$. virginica is highly adapted to life in a fluctuating environment.
\end{abstract}

\section{INTRODUCTION}

While the American oyster Crassostrea virginica (Gmelin) is widely distributed and commercially important, there have been few studies dealing with its physiological adaptation to the environment. Living in estuarine/intertidal habitats, $C$. virginica is subject to considerable environmental variation. While Galtsoff (1964) reports that the favorable salinity range falls into 2 zones, 18 to $30 \% \mathrm{~S}$ and 5 to $18 \% \mathrm{~S}, \mathrm{C}$. virginica has been reported in salinities as low as 2 to $8 \% \mathrm{~S}$ (Loosanoff and Smith, 1949; Gunter, 1955; Wells, 1961). Both temperature and ambient oxygen concentration are highly variable in estuarine/intertidal habitats.

When assessing the physiological consequences of environmental variation, a traditional experimental approach has been to vary one factor while holding others as constant as possible. However, the effect of any single environmental variable does not realistically reflect the natural environment. The combined action of several factors produces a far greater effect than that caused by any single factor (Galtsoff, 1964) but it is experimentally more difficult to establish meaningful relationships between the physiological effects of several environmental factors than it is to monitor tolerance levels to specific environmental variables.

The importance of the multifactor approach has been emphasized in discussions by Kinne $(1964,1971)$ and Alderdice (1972). Still, there are few studies dealing with the combined effects of salinity, temperature and oxygen concentration on oxygen consumption in molluscs. Newell et al. (1978) and Hawkins and Ultsch (1979) studied the combined effects of temperature and declining oxygen tension on oxygen uptake, Bayne (1971) and Shumway (1981) the combined effects of salinity and declining oxygen tension. To date, only Shumway and Marsden (1982, in press) have studied the combined effects of temperature, salinity and declining oxygen tension simultaneously with respect to their effect on oxygen consumption. All of these studies have demonstrated that environmental factors acting in consort yield different responses as compared 
with the same factors acting independently. Several studies on oxygen consumption of oysters have appeared (see Discussion for citations), but a clear picture as regards oxygen uptake under various environmental conditions has yet to emerge. The present study was undertaken in an effort to determine which physiological characters assist oysters to adapt to the diverse environmental conditions in which they are found.

\section{MATERIALS AND METHODS}

Small specimens (approximately 2 to $50 \mathrm{~mm}$ shell height) of Crassostrea virginica were obtained from the Long Island Oyster Farms where they had been kept in a 'heat pond' (annual temperature range 0 to $35^{\circ} \mathrm{C}$ ) in submerged racks at approximately $28 \% \mathrm{~S}$. Although the shells of such small oysters are relatively free from encrusting or commensal organisms, they were routinely scrubbed clean. Oysters were subsequently maintained in the laboratory for 2 to $3 \mathrm{wk}$ without food in 'Instant Ocean' aquaria at various temperature/ salinity combinations prior to use in experiments; thus it is the standard or basal metabolic rate reported here. During this time there was no mortality.

Oxygen uptake of individual oysters was measured using a Radiometer oxygen electrode in a closed system (Taylor and Brand, 1975a, b; Crisp et al., 1977; Shumway, 1981). External $\mathrm{PO}_{2}$ was not allowed to drop below $80 \%$ saturation unless that was the specific aim of the experiment, i.e. $\dot{V O}_{2}$ was always measured within the range of oxygen-independence. Tissue dry weights were determined by oven drying for $24 \mathrm{~h}$ at $60^{\circ} \mathrm{C}$. In experiments to determine the effect of body size on oxygen consumption, oysters in the size range 0.03 to $0.7 \mathrm{~g}$ dry flesh weight were used. In all other experiments oysters of a similar size were used (approximately $0.4 \mathrm{~g}$ dry weight) and the measured values for oxygen consumption transformed to that of a standard sized individual of $0.4 \mathrm{~g}$ using the appropriate size/oxygen uptake equation (Table 1) for the experimental salinity and temperature in question. This procedure minimized variations in the data due to weight differences between individuals.

In experiments to determine effects of salinity on oxygen uptake, 'Instant Ocean' seawater was diluted with distilled water to give the appropriate salinity. In order to determine the short-term or acute response to salinity/temperature combinations, the oysters were transferred directly from the acclimation conditions into the experimental medium. Oxygen consumption was measured after $1 \mathrm{~h}$ in the experimental medium to insure that the oysters were open and pumping.
During preliminary experiments it was found that handling caused the oysters to close their valves and to remain closed for extended periods. By gently placing the oysters into the respiration chambers $1 \mathrm{~h}$ prior to measurements, this problem was alleviated. According to Mitchell (1914) experimental temperature exerts a marked effect on the 'degree of openness': as the temperature increased the oysters were peristently open until approximately 26 to $27^{\circ} \mathrm{C}$. Between 27 and $30^{\circ} \mathrm{C}$ the oysters were slow to open, and at $30^{\circ} \mathrm{C}$ and above they closed the valves tightly. This response was not seen in the present study. Below about $7^{\circ} \mathrm{C}$ the oysters were closed or only partially open, but at or about $10^{\circ} \mathrm{C}$ they open most of the time. Loosanoff (1958) found that few oysters pumped below $3^{\circ} \mathrm{C}$; between 8 and $16^{\circ} \mathrm{C}$ pumping rates steadily increased, remaining relatively constant until $28^{\circ} \mathrm{C}$ i maximum pumping rates occurred between 28 and $32^{\circ} \mathrm{C}$, distress at $34^{\circ} \mathrm{C}$. Precise data on Mitchell's collection sites are not available, but our oysters were raised in a heated pond (often $30^{\circ} \mathrm{C}$ ).

To determine the effects of declining oxygen tension on oxygen uptake, oysters were placed in chambers under acclimation conditions and allowed to deplete completely the oxygen available. The validity of this experimental design, in which $\mathrm{PO}_{2}$ decrease is caused by oxygen consumption, has been criticized. However, Sassaman and Mangum (1972) and Taylor and Brand $(1975 a, b)$ have shown that oxygen consumption rates are unaffected by metabolite accumulation in closedchamber systems. More specifically, Galtsoff and Whipple (1931) showed that in Crassostrea virginica oxygen consumption is not affected by products of its own metabolism or to $\mathrm{pH}$ changes that could arise under such experimental conditions.

\section{Analysis of Data}

Mangum and van Winkle (1973) proposed that oxygen consumption is related to declining oxygen tension as:

$$
R=B_{\bigcirc}+B_{1} \mathrm{PO}_{2}+B_{2}\left(\mathrm{PO}_{2}\right)^{2}
$$

where: $R=$ weight specific oxygen consumption $(\mathrm{ml}$ $\mathrm{O}_{2} \mathrm{~h}^{-1} \mathrm{~g}$ dry $\mathrm{wt}^{-1}$ ); $\mathrm{PO}_{2}=$ partial pressure of oxygen; $B_{0}=$ minimum rate of oxygen uptake found at very low $\mathrm{PO}_{2} ; B_{1}=$ linear effect of $\mathrm{PO}_{2}$ on $\mathrm{R}_{;} B_{2}=$ deviation from linearity of the effect of $\mathrm{PO}_{2}$ on $R$. The equation uses data standardized to an initial value of unity. According to Mangum and van Winkle (1973), the quadratic coefficient, $B_{2}$, may be used as index of a species' ability to regulate its oxygen consumption rate in declining oxygen tensions. The more negative the value of $B 2$, the more oxygen independent the animal. 


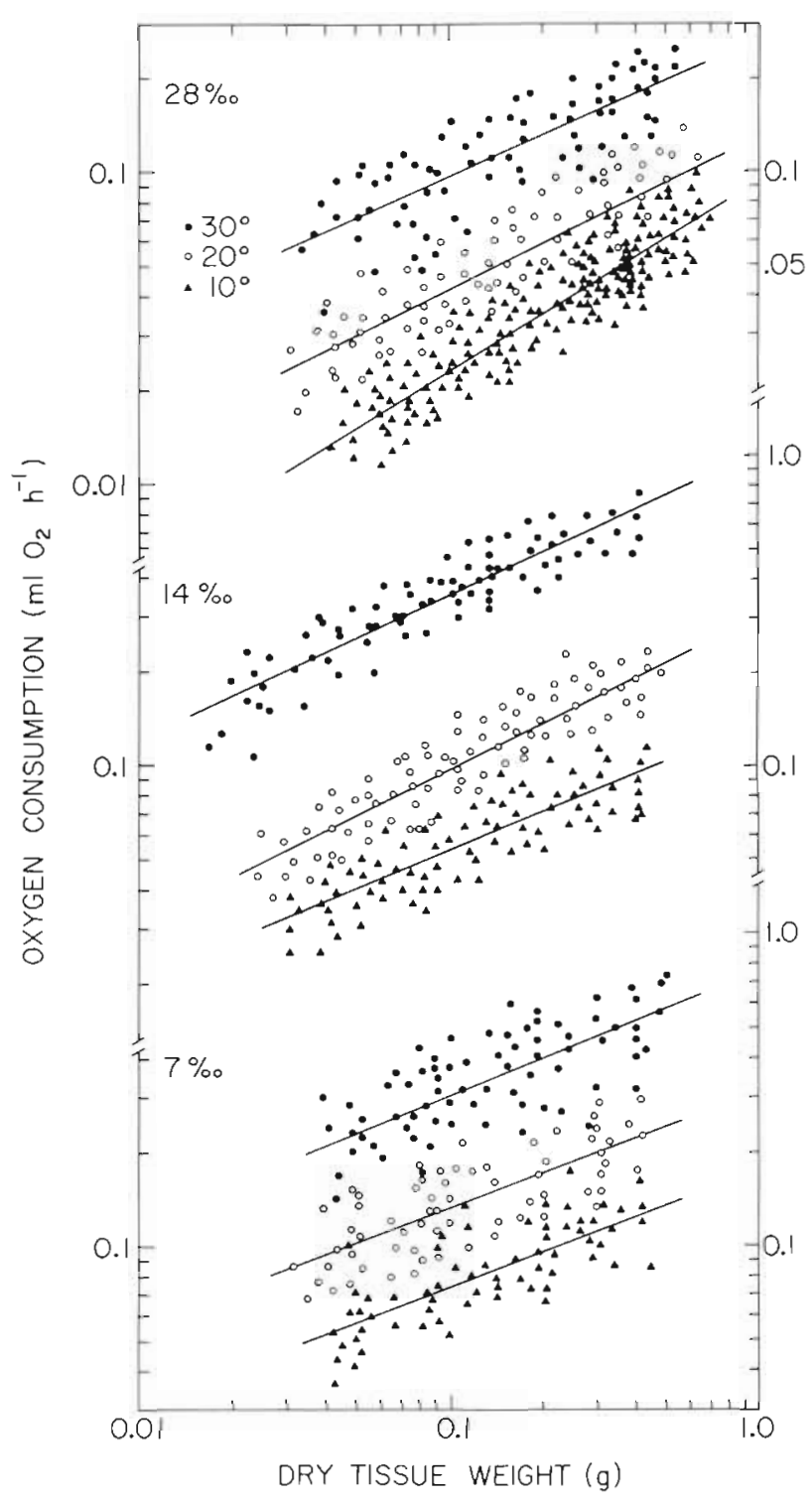

Fig. 1. Crassostrea virginica. Oxygen consumption after $3 \mathrm{wk}$ acclimation to each of 9 temperature-salinity combinations

Multiple regression equations were used to provide a concise means of describing the relationships between temperature, salinity and oxygen consumption rates under various experimental conditions. Multiple regressions were determined by the method of least squares, and the proportion of the total variance in oxygen uptake explained by individual variables was determined by analysis of variance.

The 3 dimensional diagrams relating oxygen consumption temperature and declining oxygen tension were computer-plotted using a program by F. J. Rohlf, designed to plot a surface with a halo effect on hidden lines. All analyses and graphs were done on homoscedactic means of 10 individuals.

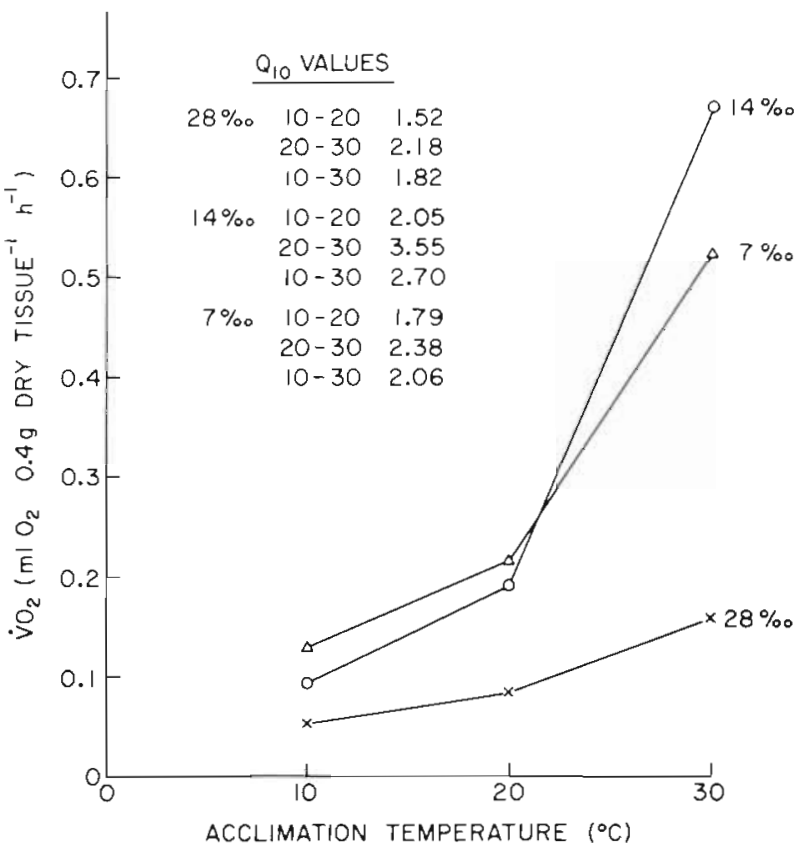

Fig. 2. Crassostrea virginica. Effect of acclimation to different temperatures and salinities on $\mathrm{V} \mathrm{O}_{2}$. Data for 'standard' oyster of $0.4 \mathrm{~g}$. Values calculated from equations in Table 1

Table 1. Crassostrea virginica. Parameters of the linear regression equation $\left(\dot{V}_{2}=a W^{b}\right)$ relating oxygen consumption $\left(\dot{\mathrm{VO}}_{2} ; \mathrm{ml} \mathrm{h}^{-1}\right)$ to dry tissue weight $(\mathrm{W} ; \mathrm{g}) ; n$ : number of determinations; $r$ : correlation coefficient; S: salinity $(\% \mathrm{~S}) ; \mathrm{T}$ : temperature $\left({ }^{\circ} \mathrm{C}\right)$ of acclimation

\begin{tabular}{|ccccccccc|}
\hline $\mathrm{S}$ & $\mathrm{T}$ & $\mathrm{a} \pm \mathrm{s} . \mathrm{d}$. & \multicolumn{2}{c}{$\mathrm{b} \pm \mathrm{s} . \mathrm{d}}$. & \multicolumn{2}{c}{$n$} & $r$ \\
\hline \multirow{2}{*}{28} & 10 & 0.094 & .017 & 0.601 & .022 & 175 & 0.899 \\
& 20 & 0.128 & .048 & 0.480 & .051 & 75 & 0.740 \\
& 30 & 0.271 & .034 & 0.449 & .038 & 76 & 0.807 \\
14 & 10 & 0.132 & .030 & 0.398 & .030 & 80 & 0.830 \\
& 20 & 0.292 & .030 & 0.482 & .030 & 83 & 0.870 \\
& 30 & 1.016 & .028 & 0.460 & .028 & 80 & 0.900 \\
7 & 10 & 0.173 & .035 & 0.375 & .038 & 63 & 0.788 \\
& 20 & 0.308 & .038 & 0.370 & .039 & 68 & 0.761 \\
& 30 & 0.759 & .047 & 0.410 & .051 & 73 & 0.689 \\
\hline
\end{tabular}

\section{RESULTS}

Oxygen consumption in Crassostrea virginica was measured in air-saturated seawater at 9 different temperature-salinity combinations over a 10 -fold size range (Figs. 1 and 2). The data were fitted to the equation: $\dot{\mathrm{V}} \mathrm{O}_{2}=a W_{b_{1}}$ where $\dot{\mathrm{VO}}_{2}=$ oxygen consumption in $\mathrm{ml} \mathrm{h}-1 ; W=$ tissue dry weight in $\mathrm{g}_{i}$ $a=$ intercept; $b=$ weight exponent. Regression data for Fig. 1 are listed in Table 1.

At any given salinity, temperature markedly affected 
Table 2. Crassostrea virginica. $\dot{\mathrm{VO}}_{2}\left(\mathrm{ml} \mathrm{O}_{2} 0.4 \mathrm{~g}^{-1} \mathrm{~h}^{-1}\right)$ for individuals acclimated to 9 temperature-salinity combinations and exposed to the same 9 combinations (i.e. the diagonal gives acclimated rates). Each point is a mean of 6 determinations. Mean standard deviation for all determinations is 0.029

\begin{tabular}{|c|c|c|c|c|c|c|c|c|c|}
\hline \multirow[b]{3}{*}{$\begin{array}{l}\text { Acclimation } \\
\text { conditions }\end{array}$} & \multicolumn{9}{|c|}{ Experimental conditions } \\
\hline & \multicolumn{3}{|c|}{$28 \% \mathrm{~S}$} & \multicolumn{3}{|c|}{$14 \% \mathrm{~S}$} & \multicolumn{3}{|c|}{$7 \% \mathrm{~S}$} \\
\hline & $10^{\circ} \mathrm{C}$ & $20^{\circ} \mathrm{C}$ & $30^{\circ} \mathrm{C}$ & $10^{\circ} \mathrm{C}$ & $20^{\circ} \mathrm{C}$ & $30^{\circ} \mathrm{C}$ & $10^{\circ} \mathrm{C}$ & $20^{\circ} \mathrm{C}$ & $30^{\circ} \mathrm{C}$ \\
\hline \multicolumn{10}{|l|}{$28 \% \mathrm{~S}$} \\
\hline 10 & 0.0531 & 0.1211 & 0.2174 & 0.0951 & 0.1713 & 0.4122 & 0.1484 & 0.3603 & 0.5068 \\
\hline 20 & 0.0335 & 0.0962 & 0.2196 & 0.1748 & 0.2100 & 0.5193 & 0.1590 & 0.2505 & 0.4248 \\
\hline 30 & 0.1210 & 0.0594 & 0.1783 & 0.1122 & 0.3965 & 0.6742 & 0.0408 & 0.2344 & 0.5264 \\
\hline \multicolumn{10}{|l|}{$14 \% \mathrm{~S}$} \\
\hline 10 & 0.0809 & 0.2005 & 0.2916 & 0.0933 & 0.2298 & 0.4710 & 0.1072 & 0.2489 & 0.4349 \\
\hline 20 & 0.0542 & 0.2166 & 0.4007 & 0.0892 & 0.1845 & 0.4538 & 0.0693 & 0.2740 & 0.4901 \\
\hline 30 & 0.0652 & 0.2114 & 0.2351 & 0.0472 & 0.3171 & 0.6216 & 0.0351 & 0.3512 & 0.5532 \\
\hline \multicolumn{10}{|l|}{$7 \% \mathrm{~S}$} \\
\hline 10 & 0.0582 & 0.2849 & 0.4500 & 0.1040 & 0.2925 & 0.4849 & 0.1371 & 0.2752 & 0.5191 \\
\hline 20 & 0.1224 & 0.2491 & 0.4907 & 0.1352 & 0.2542 & 0.4671 & 0.1114 & 0.2464 & 0.4624 \\
\hline 30 & 0.0867 & 0.2296 & 0.5243 & 0.0402 & 0.2003 & 0.4351 & 0.0704 & 0.3001 & 0.5031 \\
\hline
\end{tabular}

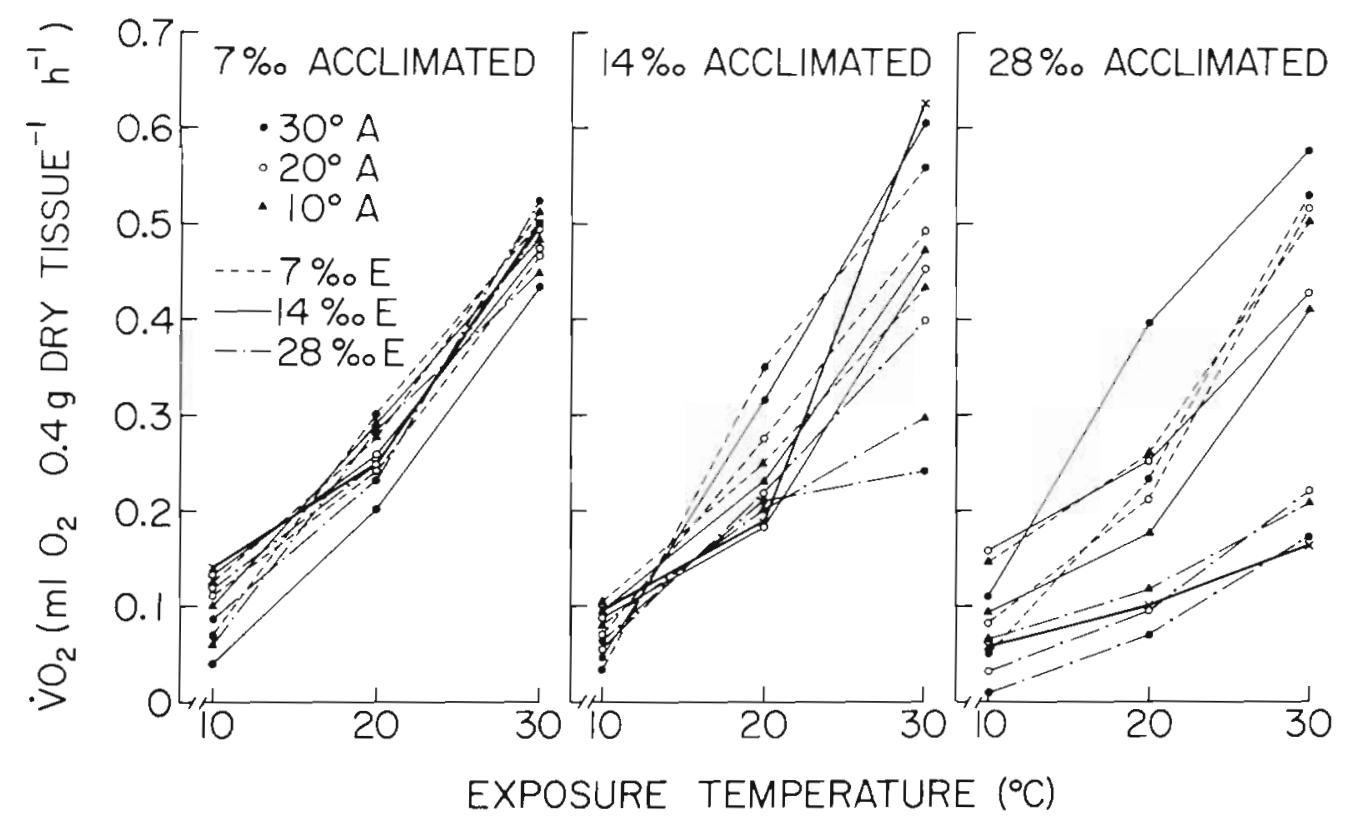

Fig. 3. Crassostrea virginica. Acute rate: temperature curves for oxygen consumption following 3 wk acclimation to 9 temperature-salinity combinations. The acclimated rate is indicated on each graph (from Fig. 2) for comparison. A: acclimated condition; E: experimental condition

the $\mathrm{VO}_{2}$. The oxygen consumption rate increased significantly with each $10 \mathrm{C}^{\circ}$ rise in temperature (Fig. 2). At both 10 and $20^{\circ} \mathrm{C}$, the rate of oxygen uptake increased with decreasing salinity. However, at $30^{\circ} \mathrm{C}$, oxygen consumption was maximal at $14 \% \mathrm{~S}$ rather than $7 \%$ S.

Values for the weight exponent $b$ ranged from 0.370 to 0.601 (Table 1) and imply at least some surface-area dependence for oxygen uptake. These values are lower than reported for other bivalves (e.g., Dame, 1972a; Ansell, 1973; Bayne et al., 1976; Newell et al., 1977). Krüger (1960) suggested that a minimum of a 50-fold size range is needed to estimate accurately the value of $b$. The low values reported here most likely reflect the narrow size range of individuals used in our experiments. 
Table 3. Crassostrea virginica. Multiple regression equations relating $\dot{\mathrm{V}} \mathrm{O}_{2}\left(\mathrm{ml} \mathrm{O} \mathrm{O}_{2} 0.4 \mathrm{~g}^{-1} \mathrm{~h}^{-1}\right)$ to acclimation $\left(\mathrm{T}_{1}, \mathrm{~S}_{1}\right)$ and experimental $\left(\mathrm{T}_{2}, \mathrm{~S}_{2}\right)$ temperatures and salinities

\begin{tabular}{|cccc|}
\hline $\begin{array}{c}\text { Acclimation } \\
\text { conditions }\end{array}$ & Regression equation & $\Gamma$ \\
\hline $28 \% \mathrm{~S}$ & $10^{\circ} \mathrm{C}$ & $\mathrm{R}=0.0160+0.0140 \mathrm{~T}_{2}-0.0095 \mathrm{~S}_{2}$ & 0.950 \\
& $20^{\circ} \mathrm{C}$ & $\mathrm{R}=0.1050+0.0133 \mathrm{~T}_{2}-0.0085 \mathrm{~S}_{2}$ & 0.910 \\
& $30^{\circ} \mathrm{C}$ & $\mathrm{R}=0.0181+0.0202 \mathrm{~T}_{2}-0.0107 \mathrm{~S}_{2}$ & 0.859 \\
$14 \% \mathrm{~S} \quad 10^{\circ} \mathrm{C}$ & $\mathrm{R}=-0.0048+0.0153 \mathrm{~T}_{2}-0.0037 \mathrm{~S}_{2}$ & 0.965 \\
& $20^{\circ} \mathrm{C}$ & $\mathrm{R}=-0.0902+0.0189 \mathrm{~T}_{2}-0.0024 \mathrm{~S}_{2}$ & 0.984 \\
& $30^{\circ} \mathrm{C}$ & $\mathrm{R}=-0.0286+0.0210 \mathrm{~T}_{2}-0.0074 \mathrm{~S}_{2}$ & 0.913 \\
$7 \% \mathrm{~S}$ & $10^{\circ} \mathrm{C}$ & $\mathrm{R}=-0.0597+0.0192 \mathrm{~T}_{2}-0.0022 \mathrm{~S}_{2}$ & 0.994 \\
& $20^{\circ} \mathrm{C}$ & $\mathrm{R}=-0.0779+0.0175 \mathrm{~T}_{2}-0.0006 \mathrm{~S}_{2}$ & 0.986 \\
& $30^{\circ} \mathrm{C}$ & $\mathrm{R}=-0.1580+0.0211 \mathrm{~T}_{2}+0.0001 \mathrm{~S}_{2}$ & 0.977 \\
& & & \\
\hline
\end{tabular}

\section{Acute Response to Temperature/Salinity Change}

Acute effects of exposure to various temperature and salinity combinations on oxygen consumption were determined for oysters acclimated to the 9 temperature-salinity combinations (Fig. 3; Table 2). These 9 equations explain 90 to $94 \%$ of the observed variation.

Oysters acclimated to $28 \% \mathrm{~S}$ revealed an elevated rate of $\mathrm{VO}_{2}$ or a translocation of the curves (Fig. 3) with the exception of individuals exposed to $28 \% \mathrm{~S}$ $(\mathrm{SE}=\mathrm{SA})$, i.e. there was some temperature compensation, dependent on salinity.

Oysters acclimated to $14 \% \mathrm{~S}$ do not exhibit such a clear response. At $20^{\circ} \mathrm{C}$ they show a slightly elevated rate, at $30^{\circ} \mathrm{C}$ a depressed rate (especially in $28 \% \mathrm{~S}$ ). Again, salinity exerts influence, but only at high temperatures: individuals in $28 \% \mathrm{~S}$ have lower $\mathrm{VO}_{2}$ values at $30^{\circ} \mathrm{C}$ than those in other salinities.

Analyses of variance indicated that there was no significant change in the level of $\mathrm{VO}_{2}$ at any tempera- ture-salinity combination in individuals acclimated to $7 \% \mathrm{~S}$, i. e. there was no temperature compensation.

Thus, acutely measured $\mathrm{VO}_{2}$ is clearly dependent on temperature, but to varying degrees, regardless of acclimation conditions. Further interpretation of the complex relationship between oxygen consumption, acclimation temperature and salinity, and exposure temperature and salinity is difficult without the use of a multiple regression analysis. Table 3 gives multiple regression equations relating $\dot{\mathrm{V}} \mathrm{O}_{2}$ to acclimation and exposure temperatures and salinities. These equations illustrate: (1) as acclimation salinity decreases, the effect of exposure temperature becomes more pronounced; (2) as acclimation salinity decreases, the effect of exposure salinity descreases; (3) as acclimation temperature increases, the effect of exposure salinity decreases; (4) as acclimation temperature increases, the effect of exposure temperature increases. The overall regression equation is:

$$
\begin{aligned}
R= & 0.0015+0.0004 T_{a}-0.0019 S_{a}+ \\
& 0.0178 T_{e}-0.0049 S_{e}
\end{aligned}
$$

where $R=\dot{V O}_{2}\left(\mathrm{ml} \mathrm{O}_{2} 0.4 \mathrm{~g}-1 \mathrm{~h}_{-1}\right) ; T_{a_{1}} S_{a}=$ acclimation temperature and salinity; $T_{e}, S_{e}=$ experimental temperature and salinity. This regression is significant $\left(F_{4,76}=85.64 ; \mathrm{P} 0.001\right)$ and explains $91.8 \%$ of the total variance in $\mathrm{VO}_{2}$ (486 data points). The interaction terms $T e S a$ and $T a S e$ were negligible.

With the single exception of oysters acclimated at $7 \% \mathrm{~S}$ and exposed to $28 \% \mathrm{~S}$, the Q10 values for warum-acclimated individuals are higher than those of cold adapted individuals, when exposed to low experimental temperatures (Table 4, Fig. 2), indicating that some warm acclimation had occurred. At any given experimental salinity, the highest $Q_{10}$ values were observed between 20 and $30^{\circ} \mathrm{C}$.

The multiple regression that relates $Q_{10}$ to acclima-

Table 4. Crassostrea virginica. Values of $Q_{10}$ measured at $10^{\circ} \mathrm{C}$ intervals under various experimental temperature-salinity

\begin{tabular}{|c|c|c|c|c|c|c|c|}
\hline \multirow{2}{*}{\multicolumn{2}{|c|}{ Acclimation conditions }} & \multicolumn{4}{|c|}{$\begin{array}{l}\text { Experimental conditions } \\
\qquad 14 \% \mathrm{~S}\end{array}$} & \multicolumn{2}{|c|}{$7 \%$ S } \\
\hline & & \multirow{2}{*}{$\frac{10-20^{\circ} \mathrm{C}}{2.28}$} & \multirow{2}{*}{$\frac{20-30^{\circ} \mathrm{C}}{1.80}$} & \multirow{2}{*}{$\frac{10-20^{\circ} \mathrm{C}}{1.80}$} & \multirow{2}{*}{$\frac{20-30^{\circ} \mathrm{C}}{2.41}$} & \multirow{2}{*}{$\frac{10-20^{\circ} \mathrm{C}}{2.43}$} & \multirow{2}{*}{$\frac{20-30{ }^{\circ} \mathrm{C}}{1.41}$} \\
\hline $28 \% \mathrm{~S}$ & $10^{\circ} \mathrm{C}$ & & & & & & \\
\hline & $20^{\circ} \mathrm{C}$ & 2.87 & 2.28 & 1.20 & 2.47 & 1.57 & 1.70 \\
\hline & $30^{\circ} \mathrm{C}$ & 4.91 & 3.00 & 3.53 & 1.70 & 5.74 & 2.25 \\
\hline \multirow[t]{3}{*}{$14 \% \mathrm{~S}$} & $10^{\circ} \mathrm{C}$ & 2.48 & 1.45 & 2.46 & 2.05 & 2.32 & 1.75 \\
\hline & $20^{\circ} \mathrm{C}$ & 4.00 & 1.85 & 2.07 & 2.46 & 3.95 & 1.79 \\
\hline & $30^{\circ} \mathrm{C}$ & 3.24 & 1.11 & 6.72 & 1.96 & 10.00 & 1.58 \\
\hline \multirow[t]{3}{*}{$7 \% \mathrm{~S}$} & $10^{\circ} \mathrm{C}$ & 4.90 & 1.58 & 2.81 & 1.66 & 2.01 & 1.89 \\
\hline & $20^{\circ} \mathrm{C}$ & 2.04 & 1.97 & 1.88 & 1.84 & 2.21 & 1.88 \\
\hline & $30^{\circ} \mathrm{C}$ & 2.65 & 2.28 & 4.98 & 2.17 & 4.26 & 1.68 \\
\hline
\end{tabular}
combinations 
tion and exposure salinity and temperature, using the mean of the exposure temperature range for computation is:

$$
\begin{aligned}
\mathrm{Q}_{10}= & 4.401-0.003 S_{a}+0.0674 T_{a}- \\
& 0.1457 T_{r}-0.0082 S_{e}
\end{aligned}
$$

where $S_{a}, T_{a}=$ acclimation salinity and temperature; $T_{r}=$ mean of the temperature range considered; $S_{e}=$ experimental salinity $\left(F_{4,53}=6.7498 ; \mathrm{P}<0.001\right)$. Although the regression is highly significant, it only accounts for $35.5 \%$ of the variation in $Q_{10}$ indicating that some other factor(s) is (are) influencing $Q_{10}$ values, possibly acclimation time, starvation or phase of gametogenic cycle.

\section{Declining Oxygen}

Crassostrea virginica shows remarkable capabilities for regulation of its rate of oxygen consumption over a wide range of tensions (approximately 40 to $90 \%$ saturation) in individuals acclimated to both 14 and $28 \% \mathrm{~S}$ (Fig. 4). However the capacity for regulation decreased considerably at all temperatures in individuals acclimated to $7 \% \circ \mathrm{S}$; the lowest capabilities occurred in oysters exposed to $7 \% \mathrm{~S}$ and $20^{\circ} \mathrm{C}$. The quadratic equations (see Methods and Materials), based on the standardized version of these data are given in Table 5, and the quadratic coefficients as a function of temperature and salinity are shown in Table 6. As can be seen, no clear pattern emerges regarding the $B_{2}$ values and various temperature salinity combinations, although the coefficients are clearly affected by these 2 parameters. In an attempt to correlate the capacity for regulating $\mathrm{VO}_{2}$ in declining $\mathrm{PO}_{2}$ with temperature and salinity, a multiple regression was computed from the data given in Table 6

$$
\mathrm{B}_{2}=a+b S+c T
$$

However, the line was not significant $\left(F_{2,8}=1.2456\right)$.

It would appear from Table 6 that in oysters acclimated to $28 \% \mathrm{~S}$ the ability to regulate $\mathrm{VO}_{2}$ increases at $30^{\circ} \mathrm{C}$; however, as can be seen from Fig. 4 , oysters acclimated to $28 \% \mathrm{~S}$ and $10^{\circ} \mathrm{C}$ maintain a constant $\mathrm{VO}_{2}$ between approximately 20 to $90 \%$ saturation, whereas individuals acclimated to $28 \% \mathrm{~S}$ and $30^{\circ} \mathrm{C}$ show a marked shift from oxygen independence to oxygen dependence at approximately $40 \%$ saturation. This apparent contradiction between the data in Fig. 4 and that in Tables 5 and 6 is due to the fact that the regulation of $\mathrm{VO}_{2}$ is so complete in individuals acclimated to $28 \% \mathrm{~S}$ and $10^{\circ} \mathrm{C}$ that the data are beyond the range of applicability of the quadratic model. This probably accounts, at least in part, for absence of a significant relationship between temperature, salinity

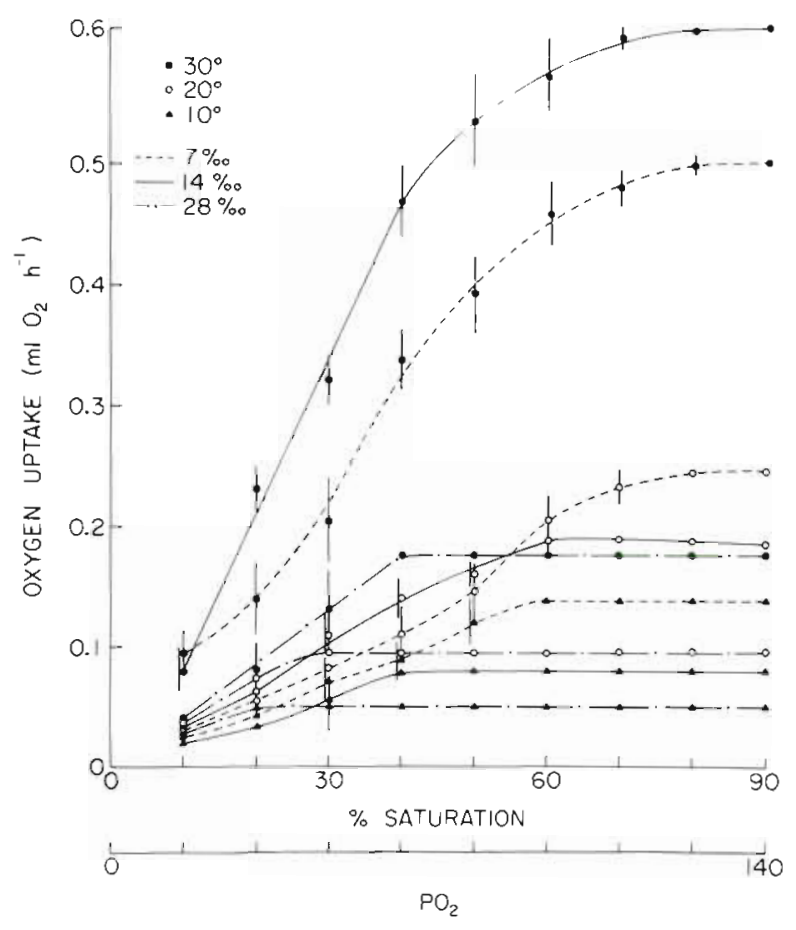

Fig. 4. Crassostrea virginica. Oxygen uptake in declining oxygen tensions after $3 \mathrm{wk}$ acclimation to each of 9 temperature salinity combinations. $\dot{\mathrm{V}} \mathrm{O}_{2}$ rates corrected for standard $0.4 \mathrm{~g}$ oyster, using equations from Table $1 . n$ : 10 ; error bars: standard deviation

Table 5. Crassostrea virginica. Values of $B_{0}, B_{1}, B_{2}$ in the expression $\dot{V} \mathrm{O}_{2}=B_{0}+B_{1} \mathrm{PO}_{2}+B_{2}\left(\mathrm{PO}_{2}\right)^{2}(r$ : correlation coefficient; $n: 10$ for each set of acclimation conditions)

\begin{tabular}{|cccccc|}
\hline $\begin{array}{c}\text { Acclimation } \\
\text { conditions }\end{array}$ & $B_{0}$ & $B_{1}$ & $B_{2}\left(\times 10^{3}\right)$ & $r$ \\
\hline $28 \% \mathrm{~S}$ & $10^{\circ} \mathrm{C}$ & 0.1530 & 0.0180 & -0.1480 & 0.701 \\
$20{ }^{\circ} \mathrm{C}$ & 0.2500 & 0.0265 & -0.2120 & 0.868 \\
& $30^{\circ} \mathrm{C}$ & -0.0753 & 0.0339 & -0.2520 & 0.971 \\
$14 \% \mathrm{~S} \quad 10^{\circ} \mathrm{C}$ & -0.0884 & 0.0336 & -0.2450 & 0.963 \\
& $20^{\circ} \mathrm{C}$ & -0.1300 & 0.0294 & -0.1880 & 0.996 \\
& $30^{\circ} \mathrm{C}$ & -0.1420 & 0.0295 & -0.1891 & 0.996 \\
$7 \% \mathrm{~S}$ & $10^{\circ} \mathrm{C}$ & -0.1390 & 0.0276 & -0.1632 & 0.982 \\
& $20^{\circ} \mathrm{C}$ & -0.0706 & 0.0160 & -0.0369 & 0.980 \\
& $30^{\circ} \mathrm{C}$ & -0.0987 & 0.0238 & -0.1260 & 0.985 \\
\hline
\end{tabular}

Table 6. Crassostrea virginica. Quadratic coefficients, $B_{2}$ $\left(\times 10^{3}\right)$ for individuals exposed to declining oxygen tensions at varying salinities and temperatures

\begin{tabular}{|cccc|}
\hline $\begin{array}{c}\text { Salinity } \\
(\%)\end{array}$ & 10 & $\begin{array}{c}\text { Temperature }\left({ }^{\circ} \mathrm{C}\right) \\
20\end{array}$ & 30 \\
\hline 28 & -0.148 & -0.212 & -0.252 \\
14 & -0.245 & -0.188 & -0.189 \\
7 & -0.163 & -0.037 & -0.126 \\
\hline
\end{tabular}


and regulatory capabilities. Thus, some caution must be used when assessing the ability of an organism to regulate oxygen consumption in declining oxygen tensions by quadratic coefficients, especially when regulation appears to be extremely good.

In general, our results demonstrate that oysters acclimated to low temperature/high salinity combinations are relatively more successful at dealing with conditions of declining oxygen tension and that the degree of oxygen independence decreases with increasing temperature and/or decreasing salinity.

$28 \%$
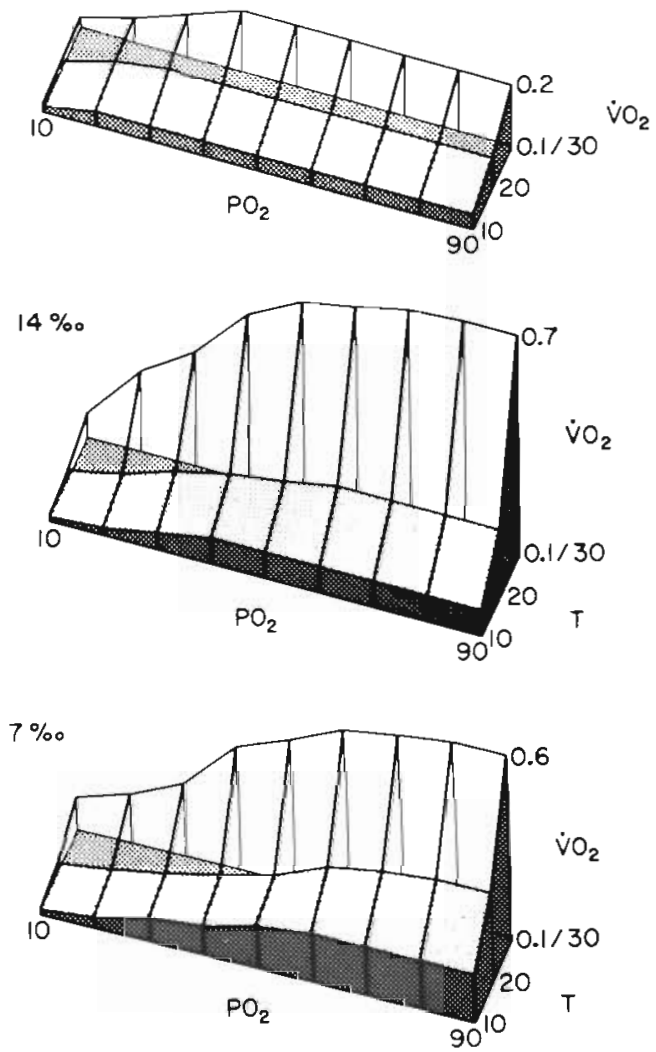

Fig. 5. Crassostrea virginica. Graphic representation of combined effects of temperature, salinity and declining oxygen tension on rate of oxygen consumption $\left(\mathrm{ml} \mathrm{O}_{2} \mathrm{~h}^{-1}\right)$. Standard individual of $0.4 \mathrm{~g}$ dry weight

The combined effects of temperature, salinity and oxygen tension on oxygen consumption rate are graphically represented in Fig. 5. It is apparent that oysters acclimated at $28 \%$ S show the highest suppressed response at all temperature- $\mathrm{PO}_{2}$ combinations. The magnitude of the responses increases with decreasing salinity. Again, it can be seen that the ability to regulate $\dot{\mathrm{VO}}_{2}$ in declining oxygen tension decreases with decreasing salinity and with increasing temperature. In addition, the combined effects of temperature and salinity are more readily visible, maximum $\mathrm{VO}_{2}$ values occurring in $14 \% \mathrm{~S}$ at $30^{\circ} \mathrm{C}$, at all oxygen tensions.

\section{DISCUSSION}

There have been many studies on oxygen consumption in oysters (Mitchell, 1914; Nozawa, 1929; Galstoff and Whipple, 1931; Sparck, 1936; Pederson, 1947; Gaarder and Eliassen, 1955; Collier, 1959; Hammen et al., 1962; Galstoff, 1964; Dame, 1972a; Bernard, 1974; Newell et al., 1977; Rodhouse, 1978). However, they were carried out over a wide range of experimental conditions, thus making comparisons between studies difficult. Most studies concern active or 'routine' rates of oxygen consumption (Bayne et al., 1976) and indicate a wide range of rates (approximate range $=0.01$ - $1.90 \mathrm{ml} \mathrm{O}_{2} \mathrm{~h}^{-1} \mathrm{~g}$ dry weight ${ }^{-1}$ ), depending on experimental conditions.

Because the oysters used in the present study were starved, the values for $\mathrm{VO}_{2}$ represent 'basal' or 'standard' rates of oxygen consumption (Bayne et al., 1976) and are therefore not directly comparable with the values of previous studies. Active and routine rates of oxygen uptake were not measured in this study, but using the data from Dame (1972b) as representing a routine rate, the basal rates reported here represent approximately 55,34 and $65 \%$ of the routine rates at 10,20 and $30^{\circ} \mathrm{C}$, respectively. These values are similar to those reported for Mytilus californianus (Bayne et al., 1976) where basal metabolic rate was approximately one half of the active (fed) rate.

Only Galtsoff (1964) has thus far reported effects of salinity on oxygen uptake in whole oysters. While no change in respiration rate occurred after $3 \mathrm{~d}$ in dilute seawater, only a narrow salinity range (31.5-24.1\% $\mathrm{S}$ ) was studied. In the present study, oxygen consumption rate of whole oysters increased with decreasing salinity at 10 and $20^{\circ} \mathrm{C}$, similar to results reported for isolated gill tissue (Persey et al., 1971; Bass, 1977). At $30^{\circ} \mathrm{C}$, however, the maximum rate was at $14 \% \mathrm{~S}$, a response similar to that reported for 'summer' oysters by Van Winkle (1958). Thus, it appears that as in Mytilus edulis (Lange, 1968), the metabolic response of Crassostrea virginica gill with respect to salinity reflects the response of intact individuals.

The metabolic response of intact oysters to temperature is not as well documented, nor do the results agree with those obtained from isolated tissues (reviewed by Shumway, 1982). Previous studies have shown that $\mathrm{VO}_{2}$ in oysters (Ostrea circumpicta, O. edulis and $C$. virginica) increases steadily from approximately 10 to $25^{\circ} \mathrm{C}$ with maximum $\mathrm{VO}_{2}$ at ca. $25^{\circ} \mathrm{C}$; below $5^{\circ} \mathrm{C}$ and above $25^{\circ} \mathrm{C}$ oxygen consumption decreases rapidly 
(Mitchell, 1914; Nozawa, 1929; Gaarder and Eliassen 1955). Dame (1972a), Newell et al., (1977) and the present study indicate that $\mathrm{VO}_{2}$ increases with increasing temperature from 5 to $30^{\circ} \mathrm{C}$, with no evidence of a suppressed rate at $30^{\circ}$.

Newell et al. (1977) found no evidence of rotation or level change of the R-T curve for routine oxygen consumption in Ostrea edulis even after $70 \mathrm{~d}$ acclimation conforming to Type 4 of Precht (1958) or Pattern I of Prosser (1967, 1973). In the present study, basal or standard rates of oxygen consumption were measured and $Q_{10}$ values for each acclimated group of oysters was determined for the intervals between each adjacent pair of test temperatures and varied from 1.11 to 10.00 (Table 4). In general, if acclimation has occurred, cold acclimated individuals have a higher $\mathrm{VO}_{2}$ and a lower $\mathrm{Q}_{10}$ at lower temperatures than warm acclimated ones which show the opposite effect at the same temperature. The $Q_{10}$ values reported here are not particularly low nor is there much evidence for capacity adaptation. As seen in Fig. 3 and described by the multiple regression equation, the oysters in the present study show partial (Precht Type 3) or no acclimation (Precht Type 4), depending on the temperature-salinity combination.

Since there is no evidence of capacity adaptation or acclimation in the oxygen consumption of Crassostrea virginica energy expenditure must increase with environmental temperature. Newell et al. (1977) reported compensatory changes in filtration rate with increasing temperature in Ostrea edulis which compensates for energy losses from metabolism; however, it remains to be seen whether $C$. virginica compensates in a similar fashion.

The responses of marine invertebrates to declining oxygen tension under otherwise 'normal' conditions, i.e. ambient temperature and salinity, have been investigated by several authors (see Newell, 1979 and Herried, 1980 for reviews), and animals have been characterized as oxygen conformers $\left(\mathrm{VO}_{2}\right.$ varies in direct proportion with $\left.\mathrm{PO}_{2}\right)$ or oxygen regulators $\left(\mathrm{VO}_{2}\right.$ is more or less independent of $\mathrm{PO}_{2}$ over some range of $\mathrm{PO}_{2}$, values below air saturation). The point at which oxygen consumption ceases to be oxygen-independent and becomes oxygen-dependent is known as critical oxygen tension $P_{c}$ ithis varies between species or individuals with temperature and/or salinity (e.g. Bayne, 1971; Newell et al., 1977; Hawkins and Ultsch, 1979; Shumway, 1981; Shumway and Marsden, 1982), body size (e. g. Bayne, 1971, 1973; Taylor and Brand, 1975b; Shumway, 1981), ventilation rate (Bayne, 1971, 1973), likelihood of experiencing hypoxia (Bayne, 1973; Murdoch and Shumway, 1980) and 'degree of openness' (Famme, 1980). With the exception of Taylor and Brand $(1975 a, b)$, Bayne $(1971,1973)$ and Famme (1980) all of the above studies were carried out with gastropods. To date, no studies in which the combined effects of temperature, salinity and declining $\mathrm{PO}_{2}$ on $\dot{\mathrm{V}} \mathrm{O}_{2}$ have been reported for bivalves.

Previous studies (Nozawa, 1929; Galtsoff and Whipple, 1931; Gaarder and Eliassen, 1955) indicate that oysters have remarkably good capabilities for regulating $\mathbf{V O}_{2}$ in declining oxygen tensions. In general, low salinity and/or high temperature appear to have the most adverse effects on $\mathrm{VO}_{2}$ in declining oxygen tensions in oysters. In the only previous study combining the effects of salinity and declining $\mathrm{PO}_{2}$ in bivalve molluscs, Bayne (1973) also found that the capacity to regulate $\dot{\mathrm{VO}}_{2}$ in dilute seawater was somewhat reduced. In contrast with the present findings, Bayne and Livingstone (1977) found that an increase in temperature from 10 to $22^{\circ} \mathrm{C}$ had no effect on the regulatory capabilities of Mytilus edulis either at air saturation or at reduced $\mathrm{PO}_{2}$.

While it has been shown here that acclimation and exposure salinity and temperature modify the effects of external oxygen tension on $\mathrm{VO}_{2}$ in Crassostrea virginica to varying degrees, the ecological significance of the ability (or lack of it) to regulate oxygen uptake at reduced oxygen tension is not clear. It appears from studies on individual tissues, as well as intact individuals that no single explanation for the effect of environmental variables on $\mathrm{VO}_{2}$ is possible in that temperature, salinity and oxygen tension all interact simultaneously. McMahon and Russell-Hunter (1974, 1977) have shown that it is the microhabitat and physiological ecology of individual species which dictates its response to declining oxygen tensions, and this appears to be the case for $C$. virginica as well.

The ability of Crassostrea virginica to sustain an energy gain from the environment then, appears to be accomplished at least in part by the possession of a rather 'elastic' or 'euryplastic' (Alderdice, 1972) physiology which allows them to utilize the available oxygen over a wide range of temperature-salinityoxygen combinations without resorting to anaerobiosis. They are thus well-adapted to life in fluctuating environmental conditions.

Acknowledgements. We are indebted to Mr. Clint Schramm of Long Island Oyster Farms for providing material and for helpful discussions; to Mr. Scott Ferson for mathematical advice; and to Professor R. C. Newell and Dr. D. Lonsdale for reading the manuscript. This research was supported by NSF grant DEB 7908862 and NIH grant GM 21133. This is contribution number 397 in Ecology and Evolution from the State University of New York, Stony Brook, New York, 11794. 


\section{LITERATURE CITED}

Alderdice, D. F. (1972). Factor combinations. Responses of marine poikilotherms to environmental factors acting in concert. In: Kinne, O. (ed.) Marine ecology, Vol. I, Environmental factors. Wiley-Interscience, London pp. 1659-1772

Ansell, A. D. (1973). Oxygen consumption by the bivalve Donax vittatus (Da Costa). J. exp. mar Biol. Ecol. 2: 311-328

Bass, E. L. (1977). Influences of temperature and salinity on oxygen consumption of tissues in the American oyster (Crassostrea virginica). Comp. Biochem. Physiol. 58B: 125-130

Bayne, B. L. (1971). Oxygen consumption by three species of lamellibranch molluscs in declining ambient oxygen tension. Comp. Biochem. Physiol. 40A: 955-970

Bayne, B. L. (1973). The responses of three species of bivalve molluscs to declining oxygen tension at reduced salinity. Comp. Biochem. Physiol. 45A: 793-806

Bayne, B. L., Bayne, C. J., Carefoot, T. C., Thomson, R. J. (1976). The physiological ecology of Mytilus californianus Conrad. 2. Adaptations to low oxygen tension and air exposure. Oecologia (Berl.) 22: 229-250

Bayne, B. L., Livingstone, D. R. (1977). Responses of Mytilus edulis L. to low oxygen tension: Acclimation of the rate of oxygen consumption. J. Comp. Physiol. B 114: 129-142

Bernard, F. R. (1974). Annual biodeposition and gross energy budget of mature pacific oysters, Crassostrea gigas. J. Fish. Res. Bd Can. 31: 185-190

Collier, A. (1959). Some observations on the respiration of the American oyster Crassostrea virginica (Gmelin). Publ. Inst. Mar. Sci. Univ. Tex. 6: 92-108

Crisp, M., Davenport, J., Shumway, S. E. (1977). Effects of feeding and of chemical stimulation on the oxygen uptake of Nassarius reticulatus (Gastropoda, Prosobranchia). J. mar. biol. Ass. U. K. 58: 387-399

Dame, R. F. (1972a). The ecological energies of growth, respiration and assimilation in the intertidal American oyster Crassostrea virginica. Mar Biol. 17: 243-250

Dame, R. F. (1972b). Allometric comparisons of some morphological characteristics of the American oyster. Fish. Bull. U.S. 70: 1121-1126

Famme, P. (1980). Effect of shell valve closure by the mussel, Mytilus edulis L. on the rate of oxygen consumption in declining oxygen tension. Comp. Biochem. Physiol. 67A: $167-170$

Gaarder, T., Eliassen, E. (1955). The energy-metabolism of Ostrea edulis. Univ. Aarbok. Naturvitenska. 3: 1-6

Galtsoff, P. S. (1964). The American oyster, Crassostrea virginica (Gmelin). Fishery Bull. Fish Wildl. Serv. U.S. 64: $1-480$

Galtsoff, P. S., Whipple, D.V. (1931). Oxygen consumption of normal and green oysters. Fish. Bull. U.S. National Marine Fisheries Service 46: 489-508

Gunter, G. (1955). Mortality of oysters and abundance of certain associates as related to salinity. Ecology 36: $601-605$

Hammen, C., Hanlon, D. P., Lum, S. C. (1062). Oxidative metabolism of Lingula. Comp. Biochem. Physiol. 19: $775-781$

Hawkins, M. J., Ultsch, G. R. (1979). Oxygen consumption in two species of freshwater snails (Goniobasis): Effects of temperature and ambient oxygen tension. Comp. Biochem. Physiol. 63A: 369-372

Herreid, C. F. (1980). Hypoxia in invertebrates. Comp. Biochem. Physiol. 67A: 311-320
Kinne, O. (1964). The effects of temperature and salinity on marine and brackish water animals. I. Temperature. Oceanogr. Mar Biol. A. Rev. 1: 301-340

Kinne, O. (1971). Salinity: Animals: Invertebrates. In: Kinne, O. (ed.) Marine ecology, Volume I, Environmental factors, Part 2. Wiley, London pp. 821-995

Krüger, F. (1960). Zur Frage der Größenabhängigkeit des Sauerstoffverbrauchs von Mytilus edulis L. Helgoländer wiss. Meeresunters. 7: 125-148

Lange, R. (1968). The relation between the oxygen consumption of isolated gill tissue of the common mussel Mytilus edulis L. and salinity. J. exp. mar. Biol. Ecol. 2: 37-45

Loosanoff, V. L. (1958). Some aspects of behavior of oysters at different temperatures. Biol. Bull. max. biol. Lab., Woods Hole 114: $57-70$

Loosanoff, V. L., Smith, P. B. (1949). Some aspects of the behavior of oysters accustomed to different salinities. Anat. Rec. 105: 627

Mangum, C. P., Van Winkle, W. (1973). Responses of aquatic invertebrates to declining oxygen conditions. Am. Zool. 13: $529-541$

McMahon, R. F., Russell-Hunter, W. D. (1974). Responses to low oxygen stress in relation to the ecology of littoral and sublittoral snails. Biol. Bull. mar. biol. Lab., Woods Hole 147: 490

McMahon, R. F., Russell-Hunter, W. D. (1977). Temperature relations of aerial and aquatic respiration in six littoral snails in relation to their vertical zonation. Biol. Bull. mar. biol. Lab., Woods Hole 152: 182-198

Mitchell, P. H. (1914). The oxygen requirements of shellfish. Bull. U. S. Bur. Fish. Vol. xxii, 1912 (1914, pp. 207-222)

Murdoch, R. C., Shumway, S. E. (1980). Oxygen consumption in six species of chitons in relation to their position on the shore. Ophelia 19: 127-144

Newell, R. C. (1979). Biology of intertidal animals, 3rd ed., Marine Ecological Surveys Ltd., Faversham, Kent

Newell, R. C., Johnson, L. G., Kofoed, L. H. (1977). Adjustment of the components of energy balance in response to temperature change in Ostrea edulis. Oecologia (Berl.) 30: $97-110$

Newell, R. C., Johnson, L. G., Kofoed, L. H. (1978). Effects of environmental temperature and hypoxia on the oxygen consumption of the suspension-feeding gastropod Crepidula fornicata L. Comp. Biochem. Physiol. 59A: 175-182

Nozawa, A. (1929). The normal and abnormal respiration in the oyster, Ostrea circumpicta Pils. Science Reports, Tohoku Imperial Univ. Fourth Series. Vol. IV Fasc. 2 Tokyo and Sendai, Japan, pp. 315-325

Pederson, E. (1947). Osterens respirasjon. Undersokelser utfort ved Statens Utklekningsanstalt Flodevigen. Rep. Norwegian Fishery and Marine Investigations, VIII, 10: $1-51$

Percy, J. A., Aldrich, F. A., Marcus, T R. (1971). Influence of environmental factors on respiration of excised tissues of american oysters, Crassostrea virginica. Can. J. Zool. 49: $353-360$

Precht, H. (1958). Concepts of the temperature adaptation of unchanging reaction systems in cold-blooded animals. In: Prosser, C. L. (ed.) Physiological adaptation. Ronald, New York, pp. 50-78

Prosser, C. L. (ed.) (1967). Molecular mechanisms of temperature adaptation. Publs. Am. Ass. Advmt Sci., Washington, D. C. (84)

Prosser, C. L. (1973). Comparative animal physiology, 3rd ed., W. B. Saunders, Philadelphia

Rodhouse, P. G. (1978). A note on the energy budget for an 
oyster population in a temperate estuary. J. exp. mar. Biol. Ecol. 37: 205-212

Sassaman, C., Mangum, C. P. (1972). Adaptations to environmental oxygen levels in infaunal and epifaunal sea anemones. Biol. Bull. max. biol. Lab., Woods Hole 143: $657-678$

Shumway, S. E. (1981). Factors affecting the oxygen consumption of the marine pulmonate Amphibola crenata. Biol. Bull. mar. biol. Lab., Woods Hole 160: 332-347

Shumway, S. E. (1982). Oxygen consumption in oysters: An overview. Mar. Biol. Letters 3; 1-23

Shumway, S. E., Marsden, I. D. (1982). The combined effects of temperature, salinity and declining oxygen tension on oxygen consumption in the marine pulmonate, Amphibola crenata. J. exp. mar. Biol. Ecol., in press
Sparck, R. (1936). On the relation between metabolism and temperature in some marine lamellibranchs, and its zoogeographical significance. Biol. Meddr 13 (5): 1-27

Taylor, A. C., Brand, A. R. (1975a). Effects of hypoxia and body size on the oxygen consumption of the bivalve Arctica islandica (L.). J. exp. mar. Biol. Ecol. 19: 187-196

Taylor, A. C., Brand, A. R. (1975b). A comparative study of the respiratory responses of the bivalves Arctica islandica (L.). and Mytilus edulis L. to declining oxygen tension. Proc. R. Soc. Lond. B 190: 443-456

Wells, H. W. (1961). The fauna of oyster beds, with special reference to the salinity factor. Ecol. Monogr. 31: 239-266 Winkle, W. van (1958). The effects of season, temperature and salinity on the oxygen consumption of bivalve gill tissue. Comp. Biochem. Physiol. 26: 69-80

This paper was presented by Professor R. C. Newell; it was accepted for printing on April 3, 1982 